\title{
PEMANFAATAN KULIT DAN DAUN SINGKONG SEBAGAI CAMPURAN BAHAN PAKAN TERNAK UNGGAS
}

\section{UTILIZATION CASSAVA SKIN AND CASSAVA LEAVES AS MIXTURE OF POULTRY FEEDING}

\author{
Hermanto, Fitriani \\ Balai Riset dan Standardisasi Industri Samarinda \\ Jl. MT. Haryono/Banggeris No.1 Samarinda \\ Email: okky9499@gmail.com
}

Diterima : 26-09-2019

Direvisi : 26-11-2019

Disetujui : 02-12-2019

\begin{abstract}
ABSTRAK
Salah satu alternatif untuk mengatasi import pakan unggas adalah dengan memanfaatkan bahan baku lokal. Tujuan dari penelitian adalah untuk menentukan formulasi pakan unggas terbaik dan mengetahui rata-rata kenaikan bobot ayam ras pedaging (broiler) yang diberi makan pakan campuran limbah kulit dan daun singkong terfermentasi. Campuran tersebut digunakan sebagai bahan baku untuk pembuatan pakan unggas dengan perbandingan $80 \%$ campuran kulit dan daun singkong terfermentasi dan $20 \%$ feed basal (tepung ikan, tepung jagung, dedak dan vitamin). Perbandingan campuran kulit dan daun singkong tersebut adalah $\mathrm{BP}_{1}$ : daun singkong $50 \%+$ kulit singkong $50 \%, \mathrm{BP}_{2}$ : daun singkong $25 \%+$ kulit singkong $75 \%, \mathrm{BP}_{3}$ : daun singkong $75 \%+$ kulit singkong $25 \%, \mathrm{BP}_{4}$ : daun singkong $100 \%$ dan $\mathrm{BP}_{5}$ : kulit singkong 100\%. Dilakukan uji mutu pakan sesuai SNI 01-3931-2006 Pakan Ayam Ras Pedaging Masa Akhir (Brolier Finisher), selanjutnya Pakan terbaik dan pakan komersil (pembanding) diuji cobakan pada ayam ras broiler yang telah berumur 20 hari, kemudian diamati dan ditimbang bobot tubuhnya setiap 5 hari sampai ayam berumur 35 hari. Hasil formulasi pakan unggas yang terbaik adalah perlakuan $\mathrm{BP}_{2}$, hasil uji coba diperoleh rata-rata kenaikan bobot ayam yang diberi pakan dari campuran limbah ikutan tanaman singkong terfermentasi adalah sebesar 40,89\% sedangkan ayam broiler yang diberi pakan ayam komersil adalah sebesar $49,49 \%$.
\end{abstract}

Kata kunci: Daun dan kulit singkong, formulasi, pakan unggas

\begin{abstract}
One alternative to cope with the import of poultry feeds is to utilize local raw materials. The purpose of this study was to determine the best formulation of poultry feed and determine the average increase in weight of broilers (broilers) fed with a mixture of skin waste and fermented cassava leaves. The mixture is used as a raw material for the manufacture of poultry feed with a ratio of $80 \%$ fermented cassava skin and leaves and $20 \%$ basal feed (fish meal, corn flour, bran and vitamins). The comparison of cassava leaves and bark mixture is BP1: $50 \%$ cassava leaf $+50 \%$ cassava skin, BP2: $25 \%$ cassava leaf $+75 \%$ cassava skin, BP3: $75 \%$ cassava leaf $+25 \%$ cassava skin, BP4: $100 \%$ cassava leaf and BP5: 100\% cassava skin. Feed quality testing was carried out according to SNI 01-3931-2006 Broiler Finisher, then the best feed and commercial feed (comparator) were tested on broilers aged 20 days, then observed and weighed their body weight each 5 days until the chicken is 35 days old. The best formulation of poultry feed is BP2 treatment, the trial results obtained an average increase in weight of chickens fed with a mixture of waste followed by fermented cassava plants is $40.89 \%$ while broiler chickens feeding with commercial chicken's feed is $49.49 \%$.
\end{abstract}

Keywords: Cassava leaves and skin, formulation, poultry feed 


\section{PENDAHULUAN}

ingkong (Manihot esculenta crantz) merupakan makanan pokok ketiga masyarakat Indonesia, selain padi dan jagung, juga merupakan tanaman berumur panjang yang sangat mudah tumbuh di daerah tropika dan mampu beradaptasi terhadap lingkungan yang tinggi namun sensitif terhadap suhu rendah. Produksi singkong di Indonesia mengalami fluktuasi setiap tahunnya, pada tahun 2014 produksi singkong sebesar 23.430,384 ton, 2015 sebesar 21.801,415 ton, 2016 sebesar 20.260,675 ton, 2017 sebesar 19.053,748 ton, dan perkiraan produksi singkong pada tahun 2018 adalah sebesar 19,341,233 ton, data diperoleh dari angka ramalan pada hasil rakor Solo, tanggal 25-27 Juli 2018, (Badan Pusat Statistik, 2017).

Provinsi Kalimantan Timur pada saat ini telah mengembangkan perkebunan singkong gajah di beberapa Kabupaten kota, singkong gajah tersebut di olah menjadi tepung tapioca dan mocaf. Permintaan akan tepung tapioca dan mocaf akhir-akhir ini semakin meningkat sehingga direncanakan akan dilakukan penambahan luasan kebun singkong. Peningkatan produksi tepung tapioca dan mocaf ini tentu saja dibarengi dengan bertambahnya limbah yang dihasilkan baik dari industri maupun perkebunan singkong itu sendiri. Limbah yang dihasilkan adalah limbah dari hasil ikutan tanaman singkong, seperti daun, batang muda dan kulitnya tersedia cukup melimpah seiring dengan meningkatnya produksi singkong setiap tahunnya.

Darmawan (2006), menyatakan bahwa; limbah berupa kulit singkong yang dihasilkan dari total produksi singkong adalah sebesar 16\%, jika 100 ton singkong diproduksi setiap harinya, maka akan didapatkan 16 ton/hari limbah kulit singkong. Menurut Rukmana (1997) menyatakan bahwa; kulit singkong mengandung bahan organik berupa karbohidrat, protein, lemak dan mineral, dan kandungan protein pada daun singkong berkisar antara $20-36 \%$ dari bahan kering. Berdasarkan data tersebut maka kulit dan daun singkong mempunyai potensi sebagai pakan sumber protein. Oleh karena itu kulit dan daun singkong dapat dimanfaatkan sebagai pakan pokok atau pakan tambahan untuk ternak. Saat ini pemanfaatan kulit singkong dan daun singkong segar sebagai pakan ternak hanya dilakukan dalam jumlah terbatas dikarenakan kulit dan daun singkong mengandung asam sianida (HCN) yang bersifat racun. Salah satu pengolahan yang dapat menurunkan kandungan sianida dalam daun dan kulit singkong adalah dengan cara proses fermentasi.

Limbah ikutan tanaman singkong terutama daun dan kulit singkong dapat dimanfaatkan sebagai pakan, dengan potensi limbah yang sangat besar dan kebutuhan akan pakan unggas yang juga sangat besar, maka dipandang perlu untuk mengolah bahan tersebut menjadi bahan pokok atau bahan campuran pakan ternak khususnya unggas. Dalam proses kegiatan budidaya ternak unggas, pakan menghabiskan biaya sekitar $60-70 \%$ dari biaya operasional sehingga perlu pengelolaan yang efektif dan efisien (Handajani, 2011). Tingkat produksi pakan di tentukan oleh nilai gizi dan harga pakan itu sendiri. Semakin tercukupi kebutuhan nutrisi pakan maka tingkat produksi unggas akan semakin tinggi. Kendala yang selalu dialami oleh para peternak unggas yaitu adanya beberapa bahan baku pakan yang masih terbilang mahal. Untuk menekan biaya produksi, dibutuhkan bahan baku pakan yang harganya relatif murah dan terjangkau serta mudah didapat.

Limbah ikutan tanaman singkong seperti kulit dan daunnya dapat diolah menjadi bahan baku pakan unggas dan dapat menjadi salah satu solusi pemecahan masalah akibat biaya pembelian pakan yang mahal. Kulit singkong kaya akan kandungan gizi, didalam $100 \mathrm{~g}$ kulit singkong terkandung protein $8,11 \mathrm{~g}$, serat kasar $15,20 \mathrm{~g}$, pectin 0,22 g, lemak 1,29 g, dan kalsium 0,63 g. Sedang daun singkong terkandung protein $6,8 \mathrm{~g}$, serat kasar 15,35 g, lemak 0,29 g dan kalsium $165 \mathrm{~g}$ (Hersoelistyorini dan Abdullah, 2012). Namun demikian kandungan senyawa beracun berupa sianida yang ada dalam kulit dan daun singkong merupakan masalah tersendiri yang membatasi pemanfaatan bahan baku ini sebagai substitusi pakan unggas (Stephanie dan Purwadaria, 2013). 
Metode fermentasi merupakan salah satu metode yang direkomendasikan untuk menghilangkan kandungan senyawa sianida dalam kulit singkong (Stephanie dan Purwadaria, 2013). Melalui proses fermentasi, asam sianida dalam kulit dan daun singkong yang berada dalam bentuk ikatan glikosida terhidrolisis dan akan terurai menjadi glukosa, aseton dan HCN. Seperti yang telah dilaporkan oleh Almasyhuri (2013) bahwa kandungan sianida dalam singkong pahit mengalami penurunan 100 persen dengan fermentasi menggunakan Rhizopus oryzae.

Tujuan dari penelitian ini adalah untuk menentukan formulasi pakan unggas terbaik dan mengetahui rata-rata kenaikan bobot ayam ras pedaging (broiler) yang di beri pakan dari campuran limbah ikutan tanaman singkong fermentasi.

\section{METODE PENELITIAN}

\section{Bahan}

Bahan yang digunakan dalam penelitian ini yaitu kulit dan daun singkong yang diperoleh dari kebun petani atau dari pabrik tepung tapioka (mocaf), ragi tape, gula, bahan-bahan kimia untuk pengujian, vitamin dan mineral, anak ayam (DOC), kandang ayam, tepung jagung, dedak, tepung ikan.

\section{Alat}

Peralatan yang digunakan pada penelitian ini adalah Peralatan pengujian di laboratorium, buret, peralatan gelas, timbangan, spektrofotometer, alat destilasi, pengaduk, pisau, kompor, gunting, alat pengukus, dandang, baskom, wadah plastik, toples plastik, blender, kemasan plastik, unit alat pencetak pellet.

\section{Prosedur Penelitian}

Ruang lingkup kegiatan dilakukan melalui beberapa tahapan yaitu : penyiapan bahan baku, proses pengolahan bahan, proses pengukusan, proses fermentasi, pembuatan pakan dan uji coba.

\section{a. Penyiapan bahan baku}

Daun singkong yang diperoleh dari kebun petani dan kulit singkong dari pabrik pengolahan tepung tapioca atau mocaf dibersihkan, dicacah dan di haluskan.

\section{b. Proses Pengukusan}

Proses pengukusan dilakukan setelah kulit dan daun singkong di haluskan, kemudian dikukus selama 15 menit atau sampai matang, kemudian bahan didinginkan.

\section{c. Proses Fermentasi}

Proses fermentasi dilakukan dengan mencampurkan ragi dan gula pasir dengan limbah ikutan tanaman singkong yang telah dikukus dan didinginkan, lalu campuran tersebut di masukkan kedalam toples plastik dan ditutup rapat kemudian didiamkan/inkubasi selama waktu tertentu. Hasil penelitian sebelumnya Hermanto et al. (2017), proses fermentasi terbaik yang dapat menurunkan kadar asam sianida (HCN) dan menaikan kadar protein pada kulit dan daun singkong adalah dengan melakukan fermentasi pada limbah ikutan tanaman singkong tersebut selama 4 (empat) hari dengan konsentrasi ragi tape dan gula sebesar $0,5 \%$.

\section{d. Pembuatan pakan unggas pada berbagai formulasi}

Pada tahapan ini di buat pakan ayam dari kulit dan daun singkong yang sudah di fermentasi (dengan stater ragi tape $0.5 \%$ selama 4 hari) di tambah dengan bahan-bahan lain yang merupakan bahan dasar untuk pakan unggas (feed basa), yang terdiri dari : 
tepung ikan, tepung jagung, dedak dan vitamin. Adapun perbandingan jumlah kulit dan daun singkong yang sudah di fermentasi untuk bahan baku pembuatan pakan ayam adalah sebagai berikut :

$\begin{array}{ll}\text { Bobot Pakan }\left(\mathrm{BP}_{1}\right) & \text { : daun singkong } 50 \%+\text { kulit singkong } 50 \% \\ \text { Bobot Pakan }\left(\mathrm{BP}_{2}\right) & \text { : daun singkong } 25 \%+\text { kulit singkong } 75 \% \\ \text { Bobot Pakan }\left(\mathrm{BP}_{3}\right) & \text { : daun singkong } 75 \%+\text { kulit singkong } 25 \% \\ \text { Bobot Pakan }\left(\mathrm{BP}_{4}\right) & : \text { daun singkong } 100 \% \text { (tanpa kulit singkong) } \\ \text { Bobot Pakan }\left(\mathrm{BP}_{5}\right) & : \text { kulit singkong } 100 \% \text { (tanpa daun singkong) }\end{array}$

Masing-masing bahan di campur dengan jumlah sesuai perbandingan (80\%), kemudian di tambahkan bahan-bahan tambahan lainnya (feed basa). Penambahan feed basal hanya $20 \%$ dari berat total bahan (base 100 gram). Adapun formula yang di tetapkan untuk semua perlakuan tersebut adalah :

1. Kulit dan Daun singkong $\quad: 80 \%$ dari $20 \%$ bobot total

2. Tepung Jagung

: $37 \%$ dari $20 \%$ bobot feed basal

3. Tepung ikan

: $30 \%$ dari $20 \%$ bobot feed basal

4. Dedak

: $31 \%$ dari $20 \%$ bobot feed basal

5. Vitamin

: $2 \%$ dari $20 \%$ bobot feed basal

Bahan-bahan tersebut kemudian di campur sampai merata, selanjutnya digiling dan di cetak (pellet) kemudian di kering anginkan. Semua perlakuan kemudian dianalisa di laboratorium dengan parameter : kadar air, kadar abu, kadar lemak kasar, protein, serat kasar, Kalsium, Pospor, Total Aflatoxins B1, Aflatoxins B2, Aflatoxins G1, Aflatoxins G2 dan HCN, kemudian hasilnya dibandingkan dengan syarat mutu SNI 01-3931-2006 Pakan Ayam Ras Pedaging Masa Akhir (Brolier Finisher).

\section{e. Uji coba pakan ternak unggas}

Uji coba dilakukan dengan cara memberikan pakan ayam yang telah dibuat dengan formula terbaik pada perlakuan sebelumnya, pakan ayam diberikan kepada ayam ras broiler yang telah berumur 20 hari dan diamati serta ditimbang bobot tubuhnya setiap 5 hari atau sampai ayam berumur 35 hari. Ayam akan di bagi menjadi 2 kelompok, yaitu ayam yang diberi pakan ayam yang beredar di pasaran dan ayam yang diberi pakan yang berasal dari campuran kulit dan daun singkong yang telah di fermentasi dan ditambah basal feed, kemudian dihitung prosentase kenaikan bobot tubuh ayam. Adapun Bagan proses pemanfaatan limbah (daun dan kulit singkong) sebagai bahan pakan ternak unggas sebagaimana pada gambar 1 . 


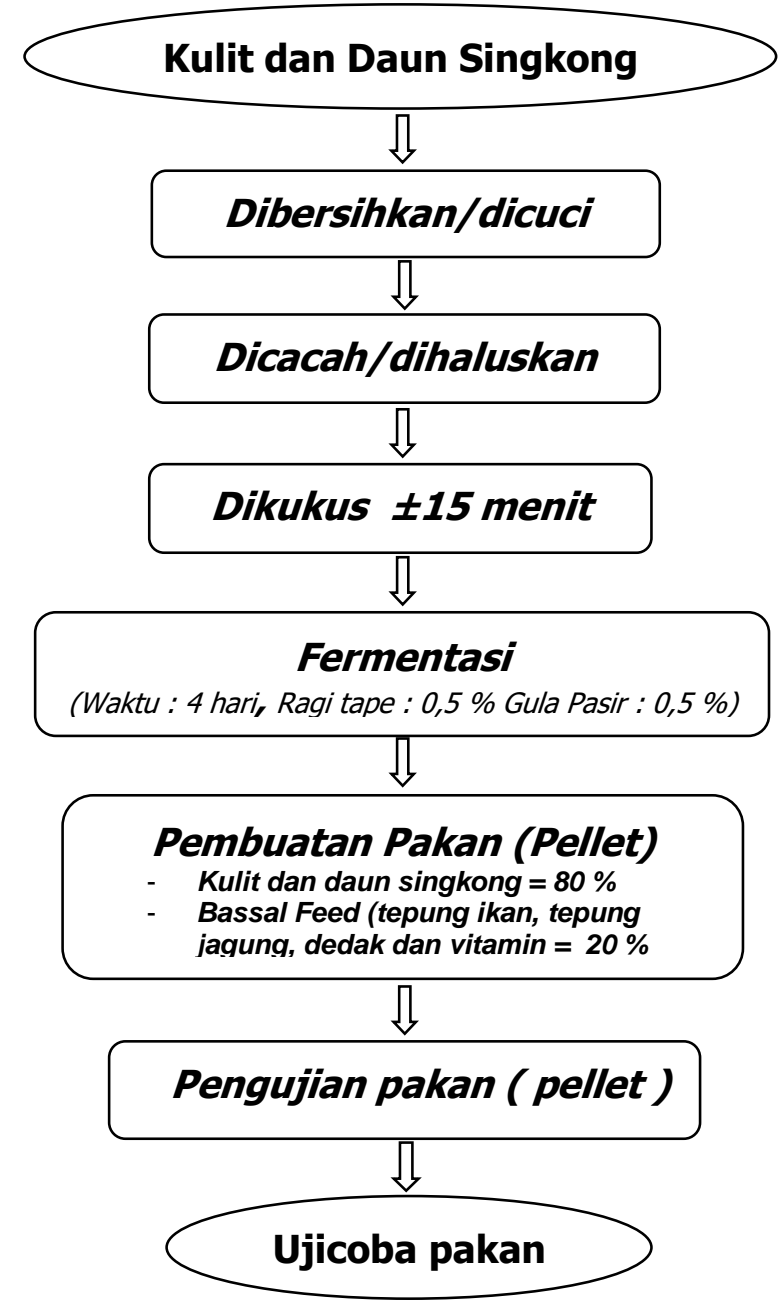

Gambar 1. Bagan proses pemanfaatan limbah (Daun dan Kulit Singkong) Sebagai bahan pakan ternak unggas (Hermanto et al., 2017).

\section{HASIL DAN PEMBAHASAN}

\section{Karakteristik Kulit dan Daun Singkong}

Kulit dan daun singkong sebelum digunakan sebagai bahan campuran untuk pakan unggas, terlebih dahulu dilakukan proses fermentasi dan analisa, hal ini di karenakan adanya kandungan zat anti nutrisi (sianida) di dalam kulit dan daun singkong tersebut. Kulit dan daun singkong mengandung protein dan serat kasar lebih tinggi dibandingkan singkong, namun selama ini kulit singkong hanya di manfaatkan sebagai pakan ternak (Pratiwi, 2013).

Saat ini pemanfaatan kulit singkong dan daun singkong segar sebagai pakan ternak hanya dilakukan dalam jumlah terbatas sebab kulit dan daun singkong mengandung asam sianida ( $\mathrm{HCN}$ ) yang bersifat racun. Salah satu pengolahan yang dapat menurunkan kandungan sianida dalam daun dan kulit singkong adalah proses fermentasi.

Menurut Hermanto et al. (2017) proses fermentasi yang dilakukan selama 4 hari dan penambahan ragi tape 0,5\% dapat menurunkan kadar asam sianida (HCN) kulit singkong dari $231 \mathrm{mg} / \mathrm{kg}$ menjadi 0,47 mg/kg terjadi penurunan 99,89\%, daun singkong dari $183 \mathrm{mg} / \mathrm{kg}$ menjadi 0,46 mg/kg terjadi penurunan 99,74\%. Sedang kenaikan kadar protein pada kulit singkong dari 4,58 \% menjadi 10,26 \% terjadi kenaikan $124,02 \%$, daun singkong dari 8,30 $\%$ menjadi $9,57 \%$ terjadi kenaikan $15,30 \%$. 
Menurut Jianping dan Yinong (2005) bagian daun dan tangkai singkong mengandung asam sianida ( $\mathrm{HCN}$ ) tertinggi, kemudian bagian kulit, batang yang terendah adalah daun yang sudah tua. Total kandungan asam sianida (HCN) pada kulit singkong berkisar antara 150 $360 \mathrm{ppm} \mathrm{mg}$ asam sianida per kg berat segar. Singkong memproduksi dua jenis senyawa glukosianida, yaitu linamarin (2- $\beta$-D-glukopiranosiloxil) dan lotaustralin (metilbutironitril) yang sebagian besar terdapat pada bagian kulit singkong (Adamafio et al., 2010).

Senyawa sianogenik dapat menyebabkan keracunan pada hewan ternak dengan tandatanda peningkatan laju pernapasan, tremor pada otot, kejang, kelenjar mukosa memerah dan bahkan kematian (Stephanie dan Purwadaria, 2013). Kadar maksimal sianogenik yang dapat ditoleransi oleh tubuh adalah $2 \mathrm{mg}$ per $\mathrm{Kg}$ berat badan untuk sapi dan domba pada pemberian tunggal.

Kulit dan daun singkong ini harus diolah terlebih dahulu agar dapat di gunakan sebagai bahan baku pakan ternak unggas. Menurut Pratiwi (2013), asam sianida (HCN) mudah hilang selama diproses, sianida hilang dalam proses perendaman, pengeringan, perebusan dan fermentasi.

\section{Formulasi Pakan Unggas (ayam)}

Dalam usaha ternak unggas (ayam boiler) kebutuhan pakan mempunyai kedudukan porsi biaya yang paling besar yaitu 60-70 \% biaya produksi. Tingginya harga pakan juga menyebabkan biaya produksi ternak menjadi tinggi, oleh karena itu diperlukan upaya agar penggunaan pakan yang ada lebih efektif dan efisien. Pakan atau Ransum berkualitas baik akan memberikan seluruh kebutuhan nutrient baik jenis, jumlah serta keseimbangan nutrient tersebut bagi ternak. Kebutuhan protein, energi, serat kasar, Ca dan $\mathrm{P}$ adalah komponen nutrient yang merupakan faktor penting yang harus diperhatikan dalam formulasi ransum broiler. Suprijatna et al. (2005) menyatakan bahwa komponen nutrient tersebut sangat mempengaruhi pertumbuhan daging pada produksi ayam broiler.

Alternatif pemecahan masalah yang dapat dilakukan adalah dengan membuat pakan unggas sendiri dengan memanfaatkan sumber-sumber bahan baku yang ada di sekitar kita (lokal) dan harganya murah serta masih memiliki kandungan nilai gizi yang baik. Bahan-bahan tersebut dapat berupa limbah yang masih layak di manfaatkan sebagai bahan baku pembuatan pakan ternak unggas (ayam). Pemanfaatan limbah adalah salah satu cara, proses dan perbuatan untuk meningkatkan nilai ekonomis suatu bahan yang tidak terpakai atau sisa suatu proses yang tidak termanfaatkan secara maksimal. Pemanfaatan limbah merupakan salah satu cara untuk menanggulangi masalah lingkungan akibat adanya produksifitas suatu pabrik dalam mengolah suatu bahan menjadi produk.

Pada tahapan ini dilakukan pembuatan pakan ayam dari kulit dan daun singkong yang telah di fermentasi menggunakan ragi tape sebanyak 0,5\% selama 4 hari, dan di tambahkan bahan - bahan lainnya (feed basal), seperti tepung jagung, dedak, tepung ikan dan vitamin pada berbagai perbandingan antara jumlah kulit dan daun singkong. Proses pembuatan pakan ternak yaitu pertama-tama mempersiapkan bahan baku kemudian dilakukan penggilingan, tujuannya untuk mendapatkan ukuran partikel yang seragam bentuknya. Selanjutnya seluruh bahan baku yang sudah digiling lalu ditimbang dan dicampur secara merata. Pakan atau bahan baku pakan adalah segala sesuatu yang dapat diberikan sebagai sumber energi dan zat-zat gizi, yang telah diolah menjadi mesh, pellet, dan crumble. 


\section{JURNAL BISET TEKNOLOH ILDUSTRB}

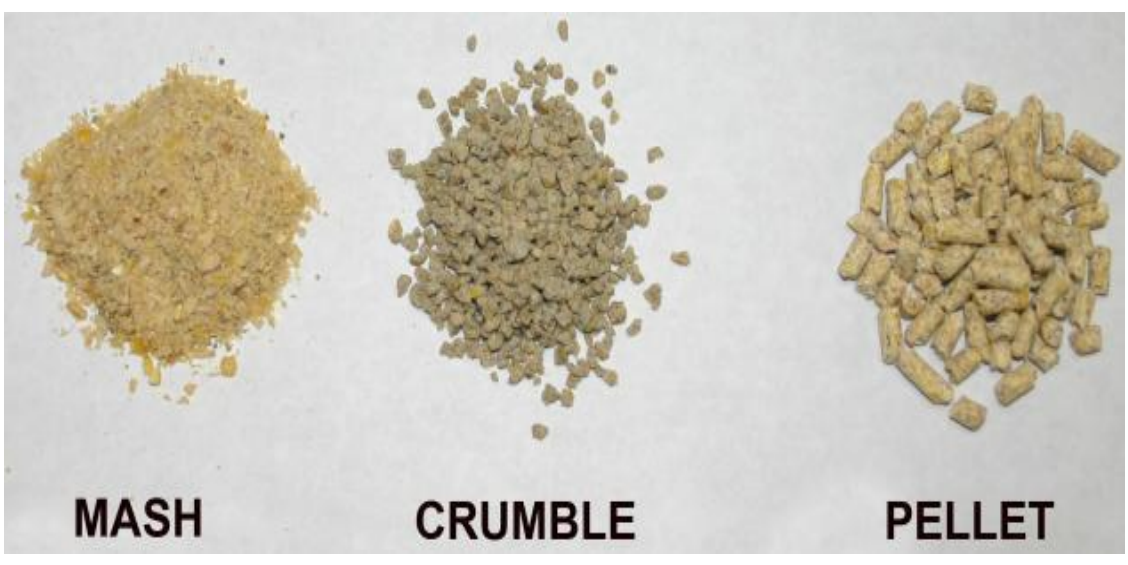

Gambar. 2 Bentuk pakan (Hermanto et al., 2017)

Semua perlakuan dianalisa di laboratorium dengan parameter : kadar air, kadar abu, kadar lemak kasar, protein, serat kasar, Kalsium, Pospor, Total Aflatoxins $\mathbf{B}_{\mathbf{1}}$, Aflatoxins $\mathbf{B}_{\mathbf{2}}$, Aflatoxins $\mathrm{G}_{1}$, Aflatoxins $\mathrm{G}_{2}$ dan kadar asam sianida ( $\mathrm{HCN}$ ), hasilnya di bandingkan dengan syarat mutu pakan ayam ras pedaging masa akhir (broiler finisher) untuk mendapatkan pakai yang terbaik. Adapun hasil pengujian pakan unggas tersebut dapat dilihat pada Tabel 1.

Tabel. 1 Data hasil pengujian pakan ternak dengan beberapa perlakuan :

\begin{tabular}{|c|c|c|c|c|}
\hline Kode & Parameter & Satuan & Hasil & SNI \\
\hline \multirow{12}{*}{$\begin{array}{l}\text { BP1 } \\
\text { KS 50\% } \\
\text { DS 50\% }\end{array}$} & Kadar Air & $\%$ & 13.62 & Maks 14 \\
\hline & Kadar Abu & $\%$ & 4.81 & Maks 6 \\
\hline & Protein kasar & $\%$ & 15.73 & Min 18 \\
\hline & Lemak kasar & $\%$ & 3.21 & Maks 8 \\
\hline & Serat Kasar & $\%$ & 0.15 & Maks 6 \\
\hline & Calcium (Ca) & $\%$ & 0.227 & $0,9-1,20 \%$ \\
\hline & Pospor (P) & $\%$ & 0.54 & Min $0,4 \%$ \\
\hline & Aflatoksin B1 & $\mathrm{mcg} / \mathrm{Kg}$ & ND (LOD 0.04) & 50 \\
\hline & Aflatoksin B2 & $\mathrm{mcg} / \mathrm{Kg}$ & ND (LOD 0.02) & 50 \\
\hline & Aflatoksin G1 & $\mathrm{mcg} / \mathrm{Kg}$ & ND (LOD 0.04) & 50 \\
\hline & Aflatoksin G2 & $\mathrm{mcg} / \mathrm{Kg}$ & ND (LOD 0.03) & 50 \\
\hline & $\mathrm{HCN}$ & $\mathrm{g} / 100 \mathrm{~g}$ & 0.003 & 3 \\
\hline \multirow{12}{*}{$\begin{array}{l}\text { BP2 } \\
\text { KS 75\% : } \\
\text { DS 25\% }\end{array}$} & Kadar Air & $\%$ & 13.81 & Maks 14 \\
\hline & Kadar Abu & $\%$ & 5.80 & Maks 6 \\
\hline & Protein kasar & $\%$ & 18.15 & Min 18 \\
\hline & Lemak kasar & $\%$ & 3.73 & Maks 8 \\
\hline & Serat Kasar & $\%$ & 0.25 & Maks 6 \\
\hline & Calcium (Ca) & $\%$ & 0.15 & $0,9-1,20 \%$ \\
\hline & Pospor (P) & $\%$ & 1.62 & Min $0,4 \%$ \\
\hline & Aflatoksin B1 & $\mathrm{mcg} / \mathrm{Kg}$ & ND (LOD 0.04) & 50 \\
\hline & Aflatoksin B2 & $\mathrm{mcg} / \mathrm{Kg}$ & ND (LOD 0.02) & 50 \\
\hline & Aflatoksin G1 & $\mathrm{mcg} / \mathrm{Kg}$ & ND (LOD 0.04) & 50 \\
\hline & Aflatoksin G2 & $\mathrm{mcg} / \mathrm{Kg}$ & ND (LOD 0.03) & 50 \\
\hline & $\mathrm{HCN}$ & $g / 100 g$ & 0.003 & 3 \\
\hline \multirow{4}{*}{$\begin{array}{l}\text { BP3 } \\
\text { KS 25\% : } \\
\text { DS 75\% }\end{array}$} & Kadar Air & $\%$ & 15.88 & Maks 14 \\
\hline & Kadar Abu & $\%$ & 6.81 & Maks 6 \\
\hline & Protein kasar & $\%$ & 16.38 & Min 18 \\
\hline & Lemak kasar & $\%$ & 2.73 & Maks 8 \\
\hline
\end{tabular}




\begin{tabular}{|c|c|c|c|c|}
\hline & Serat Kasar & $\%$ & 0.31 & Maks 6 \\
\hline & Calcium (Ca) & $\%$ & 0,09 & $0,9-1,20 \%$ \\
\hline & Pospor (P) & $\%$ & 0,56 & Min $0,4 \%$ \\
\hline & Aflatoksin B1 & $\mathrm{mcg} / \mathrm{Kg}$ & ND (LOD 0.04) & 50 \\
\hline & Aflatoksin B2 & $\mathrm{mcg} / \mathrm{Kg}$ & ND (LOD 0.02) & 50 \\
\hline & Aflatoksin G1 & $\mathrm{mcg} / \mathrm{Kg}$ & ND (LOD 0.04) & 50 \\
\hline & Aflatoksin G2 & $\mathrm{mcg} / \mathrm{Kg}$ & ND (LOD 0.03) & 50 \\
\hline & $\mathrm{HCN}$ & $\mathrm{g} / 100 \mathrm{~g}$ & 0.003 & 3 \\
\hline \multirow{12}{*}{$\begin{array}{l}\text { BP4 } \\
\text { DS 100\% }\end{array}$} & Kadar Air & $\%$ & 15.11 & Maks 14 \\
\hline & Kadar Abu & $\%$ & 2.29 & Maks 6 \\
\hline & Protein kasar & $\%$ & 16.07 & Min 18 \\
\hline & Lemak kasar & $\%$ & 3.36 & Maks 8 \\
\hline & Serat Kasar & $\%$ & 0.23 & Maks 6 \\
\hline & Calcium (Ca) & $\%$ & 0.17 & $0,9-1,20 \%$ \\
\hline & Pospor $(\mathrm{P})$ & $\%$ & 0.61 & Min $0,4 \%$ \\
\hline & Aflatoksin B1 & $\mathrm{mcg} / \mathrm{Kg}$ & ND (LOD 0.04) & 50 \\
\hline & Aflatoksin B2 & $\mathrm{mcg} / \mathrm{Kg}$ & ND (LOD 0.02) & 50 \\
\hline & Aflatoksin G1 & $\mathrm{mcg} / \mathrm{Kg}$ & ND (LOD 0.04) & 50 \\
\hline & Aflatoksin G2 & $\mathrm{mcg} / \mathrm{Kg}$ & ND (LOD 0.03) & 50 \\
\hline & $\mathrm{HCN}$ & $\mathrm{g} / 100 \mathrm{~g}$ & 0.003 & 3 \\
\hline \multirow{12}{*}{$\begin{array}{l}\text { BP5 } \\
\text { KS } 100 \%\end{array}$} & Kadar Air & $\%$ & 13.20 & Maks 14 \\
\hline & Kadar Abu & $\%$ & 5.46 & Maks 6 \\
\hline & Protein kasar & $\%$ & 18.88 & Min 18 \\
\hline & Lemak kasar & $\%$ & 5.21 & Maks 8 \\
\hline & Serat Kasar & $\%$ & 0.31 & Maks 6 \\
\hline & Calcium (Ca) & $\%$ & 0.02 & $0,9-1,20 \%$ \\
\hline & Pospor (P) & $\%$ & 0.68 & Min $0,4 \%$ \\
\hline & Aflatoksin B1 & $\mathrm{mcg} / \mathrm{Kg}$ & ND (LOD 0.04) & 50 \\
\hline & Aflatoksin B2 & $\mathrm{mcg} / \mathrm{Kg}$ & ND (LOD 0.02) & 50 \\
\hline & Aflatoksin G1 & $\mathrm{mcg} / \mathrm{Kg}$ & ND (LOD 0.04) & 50 \\
\hline & Aflatoksin G2 & $\mathrm{mcg} / \mathrm{Kg}$ & ND (LOD 0.03) & 50 \\
\hline & $\mathrm{HCN}$ & $g / 100 \mathrm{~g}$ & 0.003 & 3 \\
\hline
\end{tabular}

Keterangan : $N D=$ Not Detection

$$
\angle O D=\text { Limit Off Detection }
$$

Hasil pengujian menunjukkan bahwa dari beberapa formulasi pakan unggas yang telah di buat, formulasi yang terbaik adalah formulasi $\mathrm{BP}_{2}$ dan $\mathrm{BP}_{5}$, kedua formulasi tersebut memenuhi syarat mutu SNI 01-3931-2006 tentang Pakan Ayam Ras Pedaging Masa Akhir (Brolier Finisher). Hasil uji menunjukan bahwa dari semua parameter yang telah di uji, yang tidak memenuhi syarat mutu adalah kandungan kalsium yang terkandung didalam pakan tersebut, sedangkan parameter lainnya memenuhi syarat mutu, namun formulasi pakan $\mathrm{BP}_{2}$ memiliki kandungan kalsium yang lebih tinggi dibandingkan dengan formulasi pakan $\mathrm{BP}_{5}$, Kandungan kalsium yang masih dibawah syarat mutu yang dipersyaratkan ini dapat disebabkan karena pada jumlah tepung ikan yang ditambahkan pada pakan unggas sangat sedikit sehingga kadar kalsiumnya yang terkandung pada pakan juga menjadi kecil/sedikit. Kalsium pada umumnya terdapat pada tepung tulang ikan. Kalsium dan fosfor unsur mikro yang di butuhkan oleh hewan ternak unggas karena beberapa pertimbangan yaitu kalsium dibutuhkan oleh ternak untuk pertumbuhan dan pembentukan tulang, dimana tubuh ternak tersusun atas $70-80 \%$ kalsium dan fosfor. Disamping itu dalam pakan jadi diperlukan bahan yang $\mathrm{Ca}$ da $\mathrm{P}$ sebagai sumber mineral, bahan pakan yang mengandung sumber $\mathrm{Ca}$ dan $\mathrm{P}$, yaitu bahan baku butiran, tepung tulang dan lain sebagainya. Sedangkan efek kekurangan $\mathrm{Ca}$ 
dan $\mathrm{P}$ pada ternak mengakibatkan pertumbuhan terhambat, produksi telur dan daging menurun, tulang mudah patah, kulit telur tipis dan persendian membengkak.

Kadar protein yang terkandung dalam semua formulasi berkisar antara 15,73\% 18,88\%, terdapat beberapa formulasi yang tidak memenuhi syarat mutu SNI 01-3931-2006 Pakan Ayam Ras Pedaging Masa Akhir (Brolier Finisher), yaitu untuk perlakuan $\mathrm{BP}_{1}, \mathrm{BP}_{3}$ dan $\mathrm{BP}_{4}$, sedangkan yang memenuhi syarat mutu adalah perlakuan $\mathrm{BP}_{2}$ dan $\mathrm{BP}_{5}$. Protein merupakan salah satu unsur nutrisi yang sangat berguna untuk memperbaiki jaringan sel ternak. Protein diperlukan dalam rangka untuk pertumbuhan jaringan baru.

Data hasil uji kadar lemak kasar berkisar antara 3,21\% - 5,21\%, semua formulasi telah memenuhi syarat mutu SNI Pakan ayam ras pedaging masa akhir (Broiler Finisher). Lemak diperlukan oleh ternak untuk mengatur atau mempengaruhi pembentukan karkas, sumber lemak bisa berasal dari bahan pakan, seperti : jagung kuning, bungkil kedelai, minyak ikan dan lainnya.

Kandungan serat kasar pada limbah agroindustri dapat diurai dengan menggunakan mikroorganisme cellulotic seperti Trichoderma Sp dan Yeast Saccharomyces Cerevisiae. Pemanfaatan teknologi fermentasi dapat mengubah bahan serat kompleks menjadi komponen yang lebih sederhana, sehingga unggas dapat dan menyerap nutrient tersebut. Kandungan serat kasar pada semua formulasi pakan berkisar antara 0,23\%-0,25\%, dan angka tersebut telah memenuhi syarat mutu SNI SNI 01-3931-2006 Pakan Ayam Ras Pedaging Masa Akhir (Brolier Finisher). Fermentasi merupakan proses pemecahan senyawa organik menjadi senyawa sederhana yang melibatkan aktifitas organik. Mikroorganisme dalam proses fermentasi akan memecah serat kasar menjadi produk yang dapat dicerna oleh ternak serta dapat meningkatkan kadar protein kasar (Winarno dan Fardiaz, 1989).

Kadar air sangat berpengaruh terhadap kualitas ransum, pengurangan kadar air bertujuan untuk mengurangi berat ransum, sehingga memudahkan dan menghemat pengepakan (Winarno dan Ferdiaz, 1989). Hasil uji kadar air pakan berada pada rentang $13,62 \%-15,88 \%$, hasil kadar abu antara 2,29\% - 6,81\%, sedangkan kadar total phospor berada pada rentang $0,54 \%$ - 0,68\%, sementara hasil pengujian alfatoksin semua sampel pakan menunjukan hasil yang tidak terdeteksi dengan Limit Of Detection (LOD) berkisar antara $0.02-0.04$. Semua hasil uji tersebut telah memenuhi syarat mutu SNI 01-3931-2006 Pakan Ayam Ras Pedaging Masa Akhir (Brolier Finisher).

\section{Uji coba Pakan Ayam}

Uji coba pakan unggas dilakukan dengan memelihara ayam ras broiler yang sudah berumur 20 hari dan memberi makan ayam dengan pakan berbasis limbah ikutan tanaman singkong dengan formulasi campuran kulit dan daun singkong sebanyak $80 \%$ dan bassal feed $20 \%$, dan pembanding juga di pelihara ayam ras brolier berumur 20 hari dan diberi makan dengan pakan ayam yang beredar di pasaran (komersil). Ayam -ayam tersebut di pelihara selama 15 hari atau sampai ayam berumur 35 hari, dan setiap 5 hari dilakukan penimbangan bobot ayam. Rata-rata kenaikan bobot ayam ras brolier selama 15 hari dapat dilihat pada Gambar 3. 


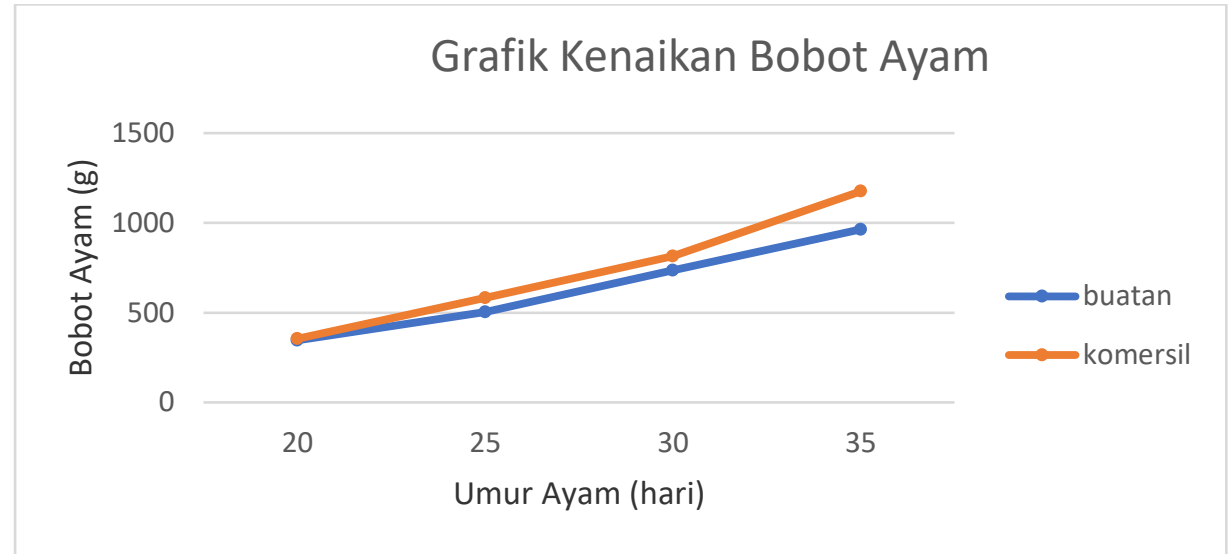

Gambar. 3 Grafik Kenaikan Bobot Ayam

Pada Gambar 3 menunjukan terjadi kenaikan bobot ayam yang di pelihara selama 15 hari dan diberi makan pakan komersil dan pakan buatan dari campuran limbah ikutan tanaman singkong yang telah difermentasi, setiap 5 hari terjadi kenaikan bobot ayam yang cukup besar, walaupun kenaikan bobot ayam yang di beri pakan berbeda tersebut menunjukkan bahwa ayam yang diberi pakan komersil kenaikan bobotnya setiap 5 hari lebih tinggi di banding ayam yang di beri pakan buatan. Data hasil kenaikan bobot ayam ( gram ) umur 20 sampai dengan 35 hari terlihat pada Gambar 3.

Tabel. 2 Data hasil kenaikan bobot ayam (gram) dari umur 20 hari s/d 35 hari

\begin{tabular}{|c|c|c|c|c|c|}
\hline No. & Jenis Pakan & $\begin{array}{c}\text { Umur Ayam } \\
\text { (hari) }\end{array}$ & Ulangan & $\begin{array}{c}\text { Bobot ayam } \\
\text { (gram) }\end{array}$ & $\begin{array}{c}\text { Rata-rata } \\
\text { (gram) }\end{array}$ \\
\hline \multirow{4}{*}{1} & \multirow{4}{*}{ Pakan Buatan } & 20 hari (awal) & $\begin{array}{l}1 \\
2 \\
3\end{array}$ & $\begin{array}{l}329,91 \\
348,75 \\
359,23 \\
\end{array}$ & 345,96 \\
\hline & & 25 hari & $\begin{array}{l}1 \\
2 \\
3\end{array}$ & $\begin{array}{l}488,12 \\
498,51 \\
525,38\end{array}$ & 504,00 \\
\hline & & 30 hari & $\begin{array}{l}1 \\
2 \\
3\end{array}$ & $\begin{array}{l}727,69 \\
742,02 \\
739,51\end{array}$ & 736,41 \\
\hline & & 35 hari & $\begin{array}{l}1 \\
2 \\
3\end{array}$ & $\begin{array}{l}958,27 \\
984,62 \\
948,33 \\
\end{array}$ & 963,74 \\
\hline \multirow{4}{*}{2} & \multirow{4}{*}{ Pakan Komersil } & 20 hari (awal) & $\begin{array}{l}1 \\
2 \\
3\end{array}$ & $\begin{array}{l}344,35 \\
361,27 \\
358,11 \\
\end{array}$ & 354,58 \\
\hline & & 25 hari & $\begin{array}{l}1 \\
2 \\
3\end{array}$ & $\begin{array}{l}592,33 \\
574,71 \\
581,06\end{array}$ & 582,70 \\
\hline & & 30 hari & $\begin{array}{l}1 \\
2 \\
3\end{array}$ & $\begin{array}{l}804,93 \\
811,65 \\
824,90\end{array}$ & 813,83 \\
\hline & & 35 hari & $\begin{array}{l}1 \\
2 \\
3\end{array}$ & $\begin{array}{l}1167,39 \\
1181,14 \\
1178,26 \\
\end{array}$ & 1175,60 \\
\hline
\end{tabular}


Rata-rata kenaikan bobot berat ayam yang diberi makan pakan ayam berbasis limbah ikutan tanaman singkong selama 15 hari adalah sebesar 40,89 \% sedang rata-rata kenaikan bobot berat ayam yang diberi makan pakan ayam komersil adalah sebesar 49,49\%. Ayam yang di beri makan pakan buatan rata-rata kenaikan bobotnya tidak sebesar ayam yang di beri makan pakan komersil, ini kemungkinan di sebabkan karena kualitas pakan buatan masih sedikit di bawah pakan komersil kandungan proteinnya. Pakan komersil mempunyai kadar protein antara 19 - 21\% sedangkan pakan buatan hanya $18,15 \%$, namun kadar protein tersebut sudah memenuhi syarat mutu SNI. Protein dalam pakan yang dikonsumsi unggas akan dicerna oleh pepsin di dalam proventriculus dan gizzard, dn enzim proteolitik (tripsin dan chimotripsin) di dalam usus halus yang menghasilkan peptida dan asam amino. Peptida dan asam amino tersebut akan di serap oleh sel mukosa usus halus unggas untuk pembentukan sel, mengganti sel mati, membentuk jaringan tubuh seperti daging, kulit, telur, embrio dan bulu. Di samping itu protein juga dibutuhkan untuk produksi telur dan sperma. Hasil pengujian pakan buatan dan pakan komersil dapat dilihat pada Tabel 3.

Tabel. 3 Tabel Perbandingan Kualitas Pakan Komersil dengan Pakan Buatan

\begin{tabular}{l|c|c|c|c}
\hline \multicolumn{1}{c|}{ Parameter } & Satuan & Pakan Buatan & $\begin{array}{c}\text { Pakan } \\
\text { Komersil }\end{array}$ & SNI \\
\hline Kadar Air & $\%$ & 13.81 & 12 & Maks 14 \\
\hline Kadar Abu & $\%$ & 5.80 & 7 & Maks 6 \\
\hline Protein kasar & $\%$ & 18.15 & $19-20$ & Min 18 \\
\hline Lemak kasar & $\%$ & 3.73 & 5 & Maks 8 \\
\hline Serat Kasar & $\%$ & 0.25 & 5 & Maks 6 \\
\hline Calcium (Ca) & $\%$ & 0.15 & $0.8-1.1$ & $0,9-1,20 \%$ \\
\hline Pospor (P) & $\%$ & 1.62 & 0.45 & Min 0,4\% \\
\hline Aflatoksin B1 & $\mathrm{mcg} / \mathrm{Kg}$ & $\mathrm{ND}($ LOD 0.04) & - & 50 \\
\hline Aflatoksin B2 & $\mathrm{mcg} / \mathrm{Kg}$ & $\mathrm{ND}($ LOD 0.02) & - & 50 \\
\hline Aflatoksin G1 & $\mathrm{mcg} / \mathrm{Kg}$ & $\mathrm{ND}($ LOD 0.04) & - & 50 \\
\hline Aflatoksin G2 & $\mathrm{mcg} / \mathrm{Kg}$ & $\mathrm{ND}($ LOD 0.03) & - & 50 \\
\hline HCN & $\mathrm{g} / 100 \mathrm{~g}$ & 0.003 & - & 50 \\
\hline
\end{tabular}

Keterangan : $N D=$ Not Detection $\angle O D=$ Limit Off Detection

Kadar lemak pada pakan buatan juga masih lebih rendah di bandingkan dengan kadar lemak yang terdapat pada pakan komersil, kadar lemak pada pakan komersil adalah sebanyak $5 \%$, sedangkan pakan buatan hanya 3,73\%, kedua pakan telah memenuhi syarat maksimal kadar lemak sesuai SNI-3931-2006 Pakan Ayam Ras Pedaging Masa Akhir (Brolier Finisher), kadar lemak di perlukan oleh ayam dalam jumlah tertentu, yaitu maksimal $8 \%$ lemak yang boleh terkandung dalam pakan ayam. Lemak dibutuhkan untuk produksi telur, lapisan lemak di antara daging dan sebagai sumber energi kebutuhan aktivitas unggas (North, 1984). Lemak pada unggas terdapat di sekitar rongga perut dan dibawah kulit, pakan yang mengandung lemak atau karbohidrat didalam tubuh unggas akan diubah menjadi lemak. Jika unggas memakan pakan yang mengandung lemak rendah maka akan menyebabkan terjadinya penurunan ukuran atau besar telur, menurunkan reproduksi pejantan serta dapat menyebabkan terganggunya pertumbuhan unggas.

Pada bahan pembuatan pakan ayam berbasis limbah ikutan tanaman singkong tersebut tidak ada penambahan bahan-bahan yang mengandung lemak, baik lemak yang berasal dari nabati maupun hewani. Sumber lemak utama : minyak sawit, minyak kelapa, minyak jagung, minyak ikan dan lemak hewan seperti tetelan dari rumah potongan hewan (North, 1984). 
Kadar mineral yang terdapat pada pakan buatan sudah memenuhi syarat SNI-39312006 Pakan Ayam Ras Pedaging Masa Akhir (Brolier Finisher), mineral pada pakan tersedia sebagai kadar Kalsium dan phosphor, Secara umum mineral adalah gizi yang dibutuhkan dalam jumlah sedikit tetapi mempunyai peranan penting dalam pembentukan kerabang telur, keseimbangan dalam sel tubuh, membantu pencernaan dan sistem transportasi gizi dalam tubuh. Kekurangan mineral pada tubuh unggas akan menyebabkan tulang unggas menjadi keropos, pertumbuhan yang tidak sehat dan tidak normal.

\section{KESIMPULAN}

Formula pakan unggas yang terbaik adalah perlakuan Bobot pakan $2\left(\mathrm{BP}_{2}\right)$ yaitu formulasi yang menggunakan substrat kulit singkong $75 \%$ dan daun singkong $25 \%$ dengan hasil analisa kadar protein kasarnya $18,15 \%$. Rata-rata kenaikan bobot berat ayam selama 15 hari dari pakan buatan ayam berbasis limbah kulit dan daun singkong adalah sebesar 40,89 $\%$ dan rata-rata kenaikan bobot berat ayam yang diberi makan pakan ayam komersil adalah sebesar 49,49\%.

\section{DAFTAR PUSTAKA}

Adamafio, NA., Sakyiamah M, dan Tettey J. 2010. Fermentation in Cassava (Manihot Esculenta Crantz) Pulp Juice Improves Nutritive Value of Cassava Peel. Afr J Biochem Res. 4(3):5156.

Almasyhuri. 2013. Pengaruh Penggunaaan Tapioka Dalam Ransum Mengandung Berbagai Tingkat Energi dan Protein Terhadap Performans Ayam Pedaging yang di Pelihara dalam Kandang Litter dan Kawat. Tesis. Program Pasca Sarjana Institut Pertanian Bogor. Bogor.

Badan Standarisasi Nasional. SNI : 01-3931-2006, SNI Pakan Ayam Ras Pedaging Masa Akhir (Brolier Finisher).

Badan Pusat Statistik. 2017. Peningkatan Produksi Singkong di Indonesia. Badan Pusat Statistik

Darmawan. 2006. Pengaruh Kulit Umbi Ketela Pohon Fermentasi Terhadap Penampilan Kambing Jantan. Jurnal IImiah I/mu-IImu Peternakan IX(2): 115-122.

Hersoelistyorini, W., dan Abdullah, MB. 2010. Biokonversi Limbah Kulit Singkong Menjadi pakan Ternak Berprotein Tinggi. Prosiding. ISBN 978-979-98465-6-3.

Handajani. 2011. Optimalisasi Substitusi Tepung Azolla Terfermentasi Pada pakan Ikan Untuk Meningkatkan Produktivitas Ikan Nila Gift. Jurnal Teknik Industri 12(2): 177-181.

Hermanto, Fitriani, Paluphy Eka Yustini, Titik Nurwidayati, Kurniawaty dan Adhitya Rinaldi, 2017. Pemanfaatan limbah ikutan tanaman singkong untuk pakan unggas. Laporan Penelitian. Balai Riset dan Standardisasi Industri Samarinda.

Jianping, L., and T. Yinong. 2005. Use of Cassava root meal and leaf silage for animal feeding in Yunnan province of China. The use of cassava roots and leaves for on farm animal feeding.

North, M.O. 1984. Comercial Chicken Production Manual $3^{\text {rd }}$ ED. The AVI Publishing Company Inc., Westport, Connecticut, USA.

Pratiwi, I.D. 2013. Pengaruh subsitusi tepung kulit singkong terhadap kualitas Muffin. Skripsi. Universitas Negeri Semarang. Semarang.

Rukmana. 1997. Ubi jalar budidaya dan pasca panen. Penerbit Kanisius Yogyakarta.

Suprijatna, E.U. Atmomarsono dan R. Kartasudjana. 2005. Ilmu Dasar Ternak Unggas. Penebar Swadaya. Jakarta.

Stephanie dan Purwadaria, T. 2013. Fermentasi substrat pada kulit singkong sebagai bahan pakan ternak unggas. Jurnal Wartazoa 23(1): 15-22.

Winarno, F. G., dan Fardiaz, S. 1989. Mikrobiologi Pangan. Departemen Pendidikan dan Kebudayaan Direktorat Jenderal Pendidikan Tinggi PAU Pangan dan Gizi IPB. 